\title{
Pre-emption: Bangladesh Approach
}

\author{
Md. Milan Hossain
}

Department of Law, Britannia University Comilla, Bangladesh

Copyright (C 2015 Horizon Research Publishing All rights reserved.

\begin{abstract}
Pre-emption is a prior right of a co-sharer of a land either by purchase or by inheritance, owner of adjoining property or neighbor of a land. When a piece of land is sold to a third party without acknowledging such owners of land, the question of right of pre-emption arises, i.e., the co-sharer of land is first entitled to purchase the land and claim the ownership. If he waves his right by consent either expressly or impliedly, a third party or a stranger can purchase it. In Bangladesh there are three legal approaches as regards pre-emption- (i) Muslim Law Approach, (ii) State Acquisition \& Tenancy Act, 1950 Approach and (iii) Non-agricultural Tenancy Act, 1949 Approach. This paper will focus on pre-emption under Muslim law and statutory laws in Bangladesh and make a comparative study. It will analyze present situation or approach of pre-emption in Bangladesh and determine the drawbacks of the existing statutory law and problems in case of application of pre-emption, and give way of solution.
\end{abstract}

Keywords Pre-emption, Co-sharer, Pre-emption Application, Muslim Law, SAT Act, NATA etc.

\section{Introduction}

In Bangladesh, the application of pre-emption was very familiar. With the change of time, the importance of pre-emption is somewhat reduced in present society due to mobiling lives. The provisions of present statutory laws, in a sense, discourage people to apply the right of pre-emption due to the rigid provisions introduced in $2006^{1}$. It reduces the numbers of application for pre-emption in civil courts comparatively.

In Bangladesh there are three approaches as regards 'Pre-emption'- one under the Muslim Law and another two under two existing laws- section 24 of the Non-agricultural Tenancy Act, 1949 (herein referred to as the NATA Act, 1949) and section 96 of the State Acquisition and Tenancy Act, 1950 (herein referred to as the SAT Act, 1950). Pre-emption of non- agricultural land is dealt under sec. 24 while sec. 96 is for agricultural land. These legal approaches

${ }^{1}$ The State Acquisition and Tenancy (Amendment) Act, 2006, (Act No. XXXIV of 2006) and present actual position of pre-emption will be focused in this paper. This article also shows the comparison between the statutory laws and Muslim law; clarifies changes introduced into the statutory laws and purposes behind the changes; determines the importance of the pre-emption in present mobilized society and gives some recommendation to implement the existing laws properly.

\subsection{Pre-emption}

Pre-emption is a right of purchasing property before or in presence to the other person. The word pre-emption was derived from the Latin 'prae' which means 'before' or 'emptions' which means 'buying'. According to Encyclopedic Law Dictionary by Dr. A.R. Biswas, pre-emption is 'the legal right of buying a thing before all others. $^{2}$

The term pre-emption is 'shuf' $a$ ' in Arabic. 'Shuf' $a$ ' means conjunction; here it denotes the right of the owner of a property which is in conjunction-that is adjacent- to another property. Haq means right. So, haq-shufa means right to subsequent purchase of a property adjacent to own from another fresh purchaser. In practice it means a right to dislodge a fresh purchaser and step in his shoes in respect of an adjacent property. It is a right to dislodge stranger from entering into ones neighbourhood. ${ }^{3}$

The right of pre-emption is not a right to repurchase, but it is a right of substitution, entitling the pre-emptor to stand in the shoes of the purchaser. This view had been adopted by the supreme court of India in Bishan Singh v. Khazan Singh ${ }^{4}$, where Subba Rao, J., summarised the rules of pre-emption thus:

(1) The right of pre-emption is not a right to the thing sold but a right to the offer of a thing about to be sold. This right is called the primary or inherent right.

(2) The pre-emptor has a secondary right or a remedial right to follow the thing sold.

(3) It is a right of substitution but not of repurchase, i.e., the pre-emptor takes the entire bargain and steps into the shoes of the original vendee.

\footnotetext{
${ }^{2}$ Lutfor Rahman, Syed. Pre-emption Laws in Bangladesh, 1st Edition, Ain-Grantha Prokashak, Dhaka, 1984 at p 1

3 Rashid, Khalid. Muslim Law, 4th Edition, Eastern Book Company, Lucknow, 2004 at p 283

${ }^{4}$ AIR 1958 SC 838
} 
(4) It is a right to acquire the whole of the property sold and not a share of the property sold.

(5) Preference being the essence of the right, the pre-emptor must have a superior right to that of the vendee or the person substituted in his place.

Pre-emption is a right by which a co-sharer in the property or the adjacent owner of an immovable property possesses to acquire by purchase another immovable property sold to another person. The law of pre-emption is as old as the Roman law. The right of pre-emption was exercised by the Romans in a contract of sale. In Indian sub-continent it was first applicable at the time of Mugal rulers of which origin is found in the Mahomedan law.

\section{Pre-emption under Muslim Law}

Muslim Law as regarding pre-emption is first approach in Bangladesh. This approach is only applicable between two Muslims but not a Muslim and non-Muslim. The right of pre-emption or Shuf' $a$ under the Mahomedan law is a right which the owner of an immovable property possesses to acquire by purchase another immovable property which has been sold to another person. This is what is meant by the right of pre-emption under Muslim law. The object underlying pre-emption under the Mahomedan law is to prevent inconvenience which may result from the introduction of disagreeable stranger as a co-partner or as a near neighbour. It is based on the ground of convenience and its objects are to prevent possible vexation arising from a disagreeable neighbour. ${ }^{5}$

Three classes of persons are entitled in Muslim law to exercise the right of pre-emption:

a) shafi-e sharik or a co-sharer in the property,

b) shafi-e khalit or a participator in immunities and appendages (a person who having right of easement, and

"No person is entitled to pre-empt unless he takes the proper steps at proper time, and conforms strictly to the necessary formalities." ${ }^{\circ}$ These formalities or ceremonies are known as the three demands.

(i) The First Demand (talab-e mowasibat): On receiving the information of the sale, the pre-emptor must make a declaration called talab-e mowsibat, asserting his intention to exercise his right of pre-emption. ${ }^{7}$ Witnesses are not necessary or any particular language or form, for making this demand. 'I have demanded or do demand pre-emption' is enough. ${ }^{8}$ The pre-emptor cannot make a delay by taking the plea that he had reason to believe the real price should be much lower than that notified to him. ${ }^{9}$

(ii) The Second Demand (talab-e ishhad): The

\footnotetext{
${ }^{5}$ Syed Sayeeduddin Ahmed v. Haji Inunus Mia, 12 DLR 93

${ }^{6}$ Fyzee, ASAF A. A. Outlines of Muhammadan Law, 4th Edition, Oxford University Press, Delhi at p. 348

7 Hedyatullah, M. and Hedayatullah, Arshad (Ed). Mulla's Principles of Mahomedan Law, 19th Edition, Tripathi, 1990, Para 236(1), p. 216

Supra Note 6, p. 348

9 Supra Note 3, p. 299
}

pre-emptor must, with the least practicable delay, make a second demand. He must (i) refer to his first demand; (ii) do so either in the presence of buyer or the purchaser or on the premises which are the subject of sale; and (iii) do so in the presence of two witnesses. This formality is called talab-e ishhad. ${ }^{10}$ This is also known as talab-e taqrir, the demand of confirmation. ${ }^{11}$ A common form of the demand is: the pre-emptor says, 'Such person has bought such house of which I am the pre-emptor (shafi). I have already claimed my privilege of pre-emption (shuf'a) and I again claim it: be ye witnesses thereof. ${ }^{12}$ The property must be clearly specified by the pre-emptor.

If the pre-emptor is at a distance and cannot be personally present, the second demand may be made by an agent, or even by a letter. If there are several purchasers, the demand must be made to all of them, unless it is made on the premises, or in the presence of the vendor. If, however, the demand is made to some only of the purchasers, the pre-emptor can claim his right as against these purchasers only, and not as against the others. ${ }^{13}$ It is not necessary for the pre-emptor to enter the house and make a demand. It is enough if he goes near the house and, touching the walls, makes the demand. This would be a sufficient compliance with the legal requirements of the second demand. ${ }^{14}$

(iii) The Third Demand (talab-e tamlik): The third demand is not only really a demand, but taking legal action, and is not always necessary; it is only when his claim is not conceded; the pre-emptor enforces his right by bringing a suit. Such an action is called talab-e tamlik or talab-e khusumat (the demand of possession, or the demand where there is a dispute). ${ }^{15}$ The suit must be brought within one year of the purchaser taking possession of the property, if it is corporeal; or within one year of the registration of the instrument of sale, if incorporeal. ${ }^{16}$ In a suit or claim for pre-emption, the whole of the interest must be claimed; a claim to a part of the estate sold is not sufficient. ${ }^{17}$

On the claim of pre-emption being enforced, the pre-emptor stands in all respects in the shoes of the buyer, and takes the property subject to prior equities. If the sale has already been completed in its entirety, the original buyer becomes the new vendor, and the pre-emptor the new purchaser. The original buyer is entitled to receive or retain the rents and mesne profits between the date of sale to himself and the date of the transfer to the pre-emptor.

\section{Pre-emption under the State Acquisition and Tenancy Act (SAT), 1950}

Section 96 of the State Acquisition and Tenancy Act, 1950

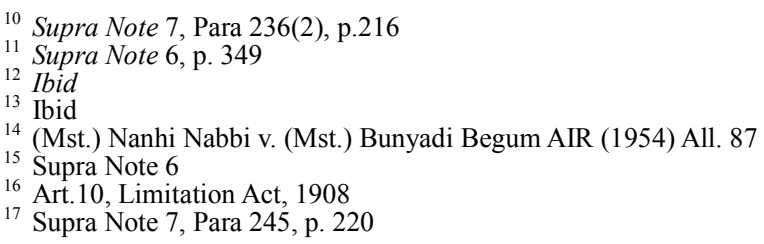

11 Supra Note 6, p. 349

13 Ibid

14 (Mst.) Nanhi Nabbi v. (Mst.) Bunyadi Begum AIR (1954) All. 87

16 Art.10, Limitation Act, 1908

17 Supra Note 7, Para 245, p. 220 
deals with the right of pre-emption. This section was substituted for the former section 96 by the Act No. XXXIV of 2006. Material changes have been made in the new section.

By the previous section, a co-sharer tenant and a tenant holding the land contiguous to the land transferred could exercise the right of pre-emption but under present section, only a co-sharer tenant of the holding by inheritance can apply for pre-emption.

Under the previous section, the right of pre-emption could be exercised when a portion or share of a holding of a rayait was transferred to any non-co-sharer tenant. In the new section, in place of the word 'transfer' the word 'sold' has been used. Use of the word 'sold' excludes any other mode of transfer and now pre-emption shall lie only against a transfer by sale. ${ }^{18}$

Under the previous section, an application for pre-emption could be brought within four months from the date of the service of the notice or from the date of the knowledge of the transfer and there was no specific maximum time barred whereas by present section it is two months which can be exercised within three years from the date of the registration of the sale deed. The right of pre-emption shall not be exercised after three years from the date of the registration of the sale deed whether the pre-emptor knows the information of sale or not; but in previous section the pre-emptor could exercise his right at any time if he could prove that he was not acknowledged of the transfer.

Now $25 \%$ compensation is accompanied with the application of pre-emption which was $10 \%$ in past. Under the previous section, there was no provision of simple interest accompanying with the application. In new section, there is provision of simple interest at the rate of eight per centum which is to be deposited with the application for pre-emption. Under the new section, there is provision of giving direction to the purchaser for executing registration deed if pre-emption is allowed; there is no such provision in the previous section.

\subsection{Rationale behind Amended Sec. 96 of the SAT Act}

Under previous section a person could exercise the right of pre-emption at any time in practically. Even a pre-emptor could exercise his right after ten years from the transfer on proving the fact that he knew it within four months and by this time he came before court. It was very hard to the purchaser who improved the land for last ten years; in exchange of it, the compensation was inadequate. It is also seen that the price of the land increased for many times. The provisions under previous section were somewhat flexible. In order to remove these problems, specific maximum time limitation is imposed and the amount of compensation is increased. Besides, in previous section a co-sharer tenant and contiguous tenant could exercise the right of pre-emption which was also a factor of bringing many applications for

\footnotetext{
${ }^{18}$ Haque, Mohammad Hamidul. Trial of Civil Suits and Criminal Cases, 2010, P. 166
}

pre-emption before the court. It was due to overload upon the court. Now this scope is limited; only a co-sharer tenant can bring an application for pre-emption under section 96 of the SAT Act. The present provisions of section 96 are somewhat rigid; it seems that this section discourages in bringing an application for pre-emption where there is no strong necessity. Under the previous section, there were drawbacks which could make harassment to the purchaser. Now it is removed by inserting the specific provisions as regards the maximum time limitation (3 years from the date of registration of the deed).

\subsection{Important Aspects of the Amended Sec. 96 of the SAT Act}

A major changes have been introduced to sec 96 of the SAT ACT by an amendment in 2006 with a view to facing the existing problems. In order to clarify the existing provisions some important aspects have been analyzed in this section.

\subsubsection{The Right of Pre-emption when Arises}

Under section 96 of the SAT Act, 1950 the right of pre-emption arises only on a sale. Section 96(1) provides that if a portion or share of a holding of a raiyat is sold to a person who is not a co-sharer tenant in the holding, one or more co-sharer tenants of the same holding may exercise their right for pre-emption. Suppose, 'A', 'B', and 'C' are three co-sharer tenants of the holding No. 570 by inheritance. Each share in the holding is respectively 20,30 and 10 decimals. ' $\mathrm{C}$ ' has sold his share in the holding to $\mathrm{X}$ who is not co-sharer tenant of the holding. Under this circumstance, ' $A$ ' \& ' $B$ ' collectively, or, 'A' or 'B' separately may exercise the right of pre-emption. Another example is required to explain it well. Suppose, ' $X$ ', ' $Y$ ' and ' $Z$ ' are co-sharer tenants of the holding No.650 by inheritance and ' $\mathrm{M}$ ' and ' $\mathrm{N}$ ' are co-sharer tenants by purchase. Their sharer's in the holding are respectively $10,15,20,10$ and 15 decimals. ' $\mathrm{Y}$ ' has sold his portion in the holding to ' $\mathrm{A}$ ' who is a stranger; not co-sharer tenant of the holding. Here, the right of pre-emption arises to ' $\mathrm{X}$ ' and ' $\mathrm{Z}$ ' but not to ' $\mathrm{M}$ ' and ' $\mathrm{N}$ ' because they are co-sharer tenants by purchase who cannot exercise the right of pre-emption under the new section. ' $\mathrm{X}$ ' and ' $\mathrm{Z}$ ', both or any of them may exercise the right of pre-emption.

Sometimes confusion arises as to the nature of the land in respect of which the pre-emption is sought for. Under section 96, an application for pre-emption lies when an agricultural land is transferred by way of sale. An agricultural land is a land which is used for the purpose of agricultural or horticulture.

\subsubsection{Requirements for Pre-emption Application under Amended Sec. 96}

\section{A. Parties to the Pre-emption Application:}

A co-sharer tenant in the holding by inheritance; and a person, to whom sale of the holding or the portion or share 
thereof, as the case may be, can be made under section 90 , can make an application for pre-emption.

The following persons are entitled to make an application for pre-emption:

a) Co-sharer tenant or tenants of a holding by inheritance (where a portion or share of a holding is sold).

b) Applicant must be tenant when a holding of a raiyat is sold.

c) Applicant must be a person to whom sale of the holding or the portion or share thereof, as the case may be, can be made under section 90 .

It is important to notify that a co-sharer tenant of the holding by purchase or a tenant holding lands contiguous to the land transferred, can not make an application for pre-emption under amended section 96. It is also important to mention that the seller cannot apply for pre-emption even though he remains a co-sharer and a party in a pre-emption application; he is merely a proper party not a necessary party because in pre-emption proceeding co-sharers are made parties in order to enable them to exercise their similar right if they so desire; but the co-sharer seller though a party, having made the sale cannot turn round and pray for pre-emption of his sold portion.

In an application for pre-emption under section 96, all other co-sharer tenants by inheritance of the holding and the purchaser shall be made parties ${ }^{19}$ (opposite parties).

B. Time limitation for Pre-emption Application:

Right of pre-emption has to be exercised within two months either:

i. from the date of service of notice of the sale (served under section 89 of the Act) by co-sharer tenants of the holding by inheritance or

ii. from the date of knowledge of sale (where no notice of the sale has been served under section 89 of the Act) by co-sharer tenants of the holding. ${ }^{20}$

It is mentionable that no application for pre-emption shall lie after the expiry of three years from the date of registration of the sale deed. ${ }^{21}$ Any of the remaining co-sharer tenants if interested may join the original application for pre-emption in the following schedule:

i. within two months from the date of service of notice of the sale (served under section 89 of the Act), or

ii. within two months from the date of knowledge of sale (where no notice of the sale has been served under section 89 of the Act), or

iii. within two months of the date of the service of the notice of the application under sub-section (4), whichever be earlier. ${ }^{22}$

Any co-sharer tenant who has not applied within the above mentioned time, he shall not exercise any further right to

\footnotetext{
${ }^{19}$ Section 96 (2), The State Acquisition and Tenancy Act, 1950, Ibid

${ }^{20}$ Section 96(1), Ibid

${ }^{21}$ Proviso of Section 96(1), Ibid

${ }^{22}$ Section 96(6), Ibid
}

purchase under the present section. It is important to note that if the original application fails on the ground of limitation, the co-applicant's prayer for pre-emption is not sustainable. If the original application is dismissed, the co-applicant's prayer shall be dismissed. If the co-applicant's prayer is allowed, he or they shall deposit the prescribed amount within the prescribed time according to the direction of the court. If he or they fail to do so, his or their applications shall be dismissed. ${ }^{23}$

\section{Other Necessary Conditions:}

The application must be accompanied by a deposit of the consideration money of the sold holding or portion or share of the holding as stated in the notice or in the deed sale together with compensation at the rate of twenty five per centum and simple annual interest at the rate of eight per centum for the period from the date of the execution of the deed of sale to the date of filing of the application for pre-emption; otherwise the application shall be dismissed. ${ }^{24}$ In case of improvement of purchased land by the purchaser, the applicant must deposit compensation on a direction of the court.

\section{The Courts Orders to a Pre-emption Application}

If an application for pre-emption is allowed, the following orders shall be passed by the court: ${ }^{25}$

a) allowing the application or applications made by the applicant or applicants who are entitled to purchase under, and have complied with the provisions of this section;

b) apportioning the holding or the portion or share of the holding among them in such manner as it deems equitable when such orders are passed in favour of more than one applicant under sub-section (8);

c) refunding money to any one if entitled to such refund of any money from the amount deposited by the applicant or applicants under sub-sections (3) and (5);

d) directing that the purchaser be paid out of the deposits made under sub-sections (3) and (5);

e) directing the purchaser to execute and register deed or deeds of sale within sixty days in favour of the person or persons whose application or applications have been allowed; and no tax, duty or fee shall be payable for such registration.

It is important to note that the court, while deciding an application under section 96, cannot cancel a deed nor can declare a deed as void, fraudulent, collusive etc. It is also mentionable that if the purchaser fails to execute and register deed or deeds of sale in the prescribed time in favour of the person or persons whose application or applications have been allowed, the court shall execute and present deed or deeds of sale for registration within sixty days thereafter in favour of such person or persons whose applications have

\footnotetext{
${ }^{23}$ Section 96(8), Ibid

24 Section 96(3), Ibid

${ }^{25}$ Section 96(9), Ibid
} 
been allowed. ${ }^{26}$

\subsection{Lacunae of the Substituted Section 96}

Some problems may arise by the new section 96; because under this section only a co-sharer tenant of the holding by inheritance is entitled to pre-empt; but there is confusion where a co-sharer tenant of the holding by purchase can pre-empt or not. If a co-sharer tenant by purchase cannot make an application, the anomalous may arise which can be explained by an example. $\mathrm{X}$ is a co-sharer who became co-sharer by purchase of the holding or khatian No.202 in 2003 and dies after few months, his heirs will become co-sharers by inheritance of that holding and will be entitled to file an application for pre-emption but $\mathrm{Y}$, a co-sharer by purchase of that holding who purchased in 1997 and is still alive, will not be entitled to file an application for pre-emption under section 96 in view of to sub-section (1).

\section{Pre-emption under the Non-Agricultural Tenancy Act (NATA), 1949}

Under section 24 of the Non-Agricultural Tenancy Act the right of pre-emption in respect of non- agricultural land is dealt. The provisions of this section attract in case of land in a municipal area. ${ }^{27}$ Pre-emption in respect of non-agricultural is only possible under section 24 of Non-Agricultural Tenancy Act. Provision of section 96 of the SAT Act is not applicable to such case. ${ }^{28}$ It cannot be said that the sub-section (2) and (3) of the SAT Act have repealed section 24 of the Non-Agricultural Tenancy Act by implication. ${ }^{29}$ The object of section 24 of the Act is to prevent non-agricultural tenancy lands from being possessed by stranger purchasers if the other co-sharer tenants desire to have the same themselves. ${ }^{30}$

"If a portion or share of the non-agricultural land held by a non-agricultural tenant is transferred, one or more co-sharer tenants of such land may, within four months of the service of notice issued under section 23 and, in case no notice had been issued or served, then within four months from the date of knowledge of such transfer, apply to the court for such portion or share to be transferred to himself or to themselves, as the case may be." 31

"The application under sub-section (1) shall be dismissed unless the applicant at the time of making it deposits in Court the amount of the consideration money or the value of the portion or share of the property transferred as stated in the notice served on the applicant under section 23 together with compensation at the rate of five per centum of such

\footnotetext{
${ }^{26}$ Section 96(10), Ibid

${ }_{27}$ Md. Abdur Rouf v. Ahmuda Khatun 33 DLR (AD) 323

28 Forman Ali Howladar v. Helaluddin Rashari and others, 20 DLR, 1197

29 Ibid

30 Shyamapada Bhattacharjee v. Satya Gopal Majumder, (1963) 67 CWN 599

${ }^{31}$ Section 24(1), The Non-Agricultural Tenancy Act, 1949
}

amount."32

\section{Comparison between Two Existing Legislations as Regards Pre-emption}

In order to understand the concept of pre-emption in respect of non-agricultural tenancy land a comparison can be drawn between section 24 of the Non-Agricultural Tenancy Act, 1949 and section 96 of the SAT Act, 1950.

Firstly, section 24 of the Non- agricultural Tenancy Act applies in respect of non-agricultural lands; on the contrary, section 96 of the SAT Act is applicable to agricultural lands.

Secondly, under section 24(1), an application for pre-emption may be made within four months of the service of notice issued under section 23 or if no notice served, within four months from the date of knowledge of the transfer; whereas under substituted section 96(1), an application for pre-emption may be made within two months of the service of notice given under section 89 of the SAT Act or if no notice served, within two months of the date of knowledge of the sale and no application shall lie after expiry of three years from the date of registration of the sale deed. Such time limitation is not mentioned in section 24.

Thirdly, the right of pre-emption conferred by section 24 is confined to the co-sharers in the tenancy. ${ }^{33}$ The right of pre-emption under substituted section 96 can only be exercised by a co-sharer tenant in the holding by inheritance and a person to whom sale of the holding or the portion or the share thereof, as the case may be, can be made under section $90 .^{34}$

Fourthly, as regards conditions: Under section 24 an application for pre-emption must be accompanied by a deposit of the consideration money of the property transferred as stated in the notice under section 23 together with compensation at the rate of five per centum thereon ${ }^{35}$; whereas under section 96 an application for pre-emption must be accompanied by a deposit of the consideration money of the sold holding or portion or share of the holding as stated in the notice under section 89 or in the deed sale together with compensation at the rate of twenty five per centum and simple annual interest at the rate of eight per centum for the period from the date of the execution of the deed of sale to the date of filing of the application for pre-emption. ${ }^{36}$ No interest is necessary to be paid, at the time of filing an application for pre-emption under section 24.

Fifthly, as regards subsequent conditions: In case of pre-emption under section 24 , the applicant or applicants have to deposit such amount as the transferee has paid (i) in respect of rent for the period after the date of transfer or (ii) in annulling encumbrances on the property and (iii) in erecting any building or structure between the date of the

\footnotetext{
${ }^{32}$ Section 24(2), Ibid

${ }_{33}$ Manindra Chandra Ghosh v. Majibul Islam, (1960) 12 DLR 785

${ }_{35}^{34}$ Supra Note 21

35 ibid

36 Supra Note 28
} 
transfer and the date of the service of notice of the application or (iv) in making any other improvement in the property transferred together with interest at the rate of six and a quarter per centum per annum from the date on which the transferee made such payment. ${ }^{37}$ On the contrary, in case of pre-emption under section 96 the applicant or applicants will be required to deposit further sum paid or expenses incurred by the purchaser on three grounds, namely, (1) in respect of rent, (2) in annulling encumbrances, and (3) for making improvements in respect of property transferred. But interest need not be paid together. ${ }^{38}$

Sixth, as regards remaining co-sharer tenants: In case of pre-emption under section 24 , any of the remaining co-sharer tenants including the transferee as co-applicants may apply to join the original application made under section 24(1) within the period of four months referred to in sub-section (1) or within one month of the service of notice of the application, whichever is later. ${ }^{39}$ But under section 96 the remaining co-sharer tenants, if interested, any of them may apply to join the original application within the period of two months referred in sub-section (1) or within the two months of the service of the notice of the application, whichever is earlier. ${ }^{40}$ There is no provision under section 96 for purchaser to join the original application as co-applicant.

Seventh, section 24 provides that in making an order allowing the application for pre-emption in favour of more than one co-sharer tenants, the court may apportion the property transferred among the applicants in such manner as it deems equitable after taking existing possession into consideration. ${ }^{41}$ The court shall so apportion the said property on the request of any applicant. But under new section 96, the court must apportion the holding or the portion or share of the holding sold among the applicants in such a manner as it deems equitable. ${ }^{42}$ The expression "after taking existing possession into consideration" is not therein section 96 .

\subsection{Comparison between Muslim Law \& Legislation as regards Pre-emption}

In Bangladesh the provision of Pre-emption under Muslim Law is only applicable between two Muslims but not between Muslim and Non-Muslim; if the dispute arise between Muslim and Non-Muslim, the statutory laws (i.e. the SAT ACT, 1950 \& the NATA Act, 1949) will be applicable. The other differences between the Muslim law and the SAT Act, 1950 are as follows:

a) The right of pre-emption under section 96 can only be exercised by a co-sharer tenant in the holding or khatian by inheritance whereas three classes of persons are entitled in Muslim law to exercise the right of pre-emption, viz. (i) shafi-e sharik (a

\footnotetext{
37 Section 24(3), Supra Note 31

38 Section 96(5), Supra Note 19

39 Section 24(4), Supra Note 31

40 Supra Note 28

41 Section 24(7), Supra Note 31

42 Section 96(9)(b), Supra Note 19
}

co-sharer in the propeerty), (ii) shafi-e khalit (who has a right of easement, right of way, water), and (iii) shafi-e jar (neighbour).

b) Under section 96 of the SAT Act, $25 \%$ as compensation on consideration money mentioned in the deed and $8 \%$ simple interest are to be deposited along with the application of pre-emption but in case of pre-emption under Muslim Law such compensation and interest are not required.

c) Under section 96(1), an application for pre-emption may be made within two months of the service of notice given under section 89 of the SAT Act or if no notice served, within two months of the date of knowledge of the sale and no application shall lie after expiry of three years from the date of registration of the sale deed whereas under Muslim law a suit for pre-emption must be brought within one year from the date of registration or from the date of acknowledgement. ${ }^{43}$

d) No formalities are to be maintained under sec 96 of the SAT Act before making an application for pre-emption but under Muslim Law some formalities must be maintained.

e) In order to bring an application for pre-emption a fixed court fee is to be paid but in case of Muslim law ad valorem court fee is to be paid.

f) Under section 96 if an application is allowed a deed is to be executed and registered by the purchaser according to the direction of the court ${ }^{44}$ whereas in case of pre-emption under Muslim law there is no such provision.

g) Under section 96 an application is to be filed for pre-emption which is known as misc case and no decree is drawn up. Under Muslim law, pre-emption case is a civil suit and a decree is drawn up.

\section{Importance of Pre-emption in the Present Society}

The concept of pre-emption came in Indian subcontinent from Muslim Law. It is inserted in the statutory laws. By applying the rules of pre-emption a co-sharer prevents a stranger; he can extend his portion in the holding or land, but the sole object is to save the co-sharers or neighbours from vexation and inconvenience of a stranger purchaser; its object is not to extend the portion or share or property of other co-sharers of a holding or land. So it carries importance but in the present society it has lost its importance somewhat. Now the society is mobilized; people do not live in a place forever. It does not matter to the people of a society who become the owner of an adjoining land or holding. Pre-emption in case of non-agricultural land or municipal area is now rare due to mobilized society.

The importance of pre-emption in village area or in case of

\footnotetext{
${ }^{43}$ Supra Note 16

${ }^{44}$ Section 96 (9)(e), Supra Note 19
} 
agricultural land can not be denied. The people of a village do not like the entrance of a stranger to their holding but now the village life is also changing. As a result, the importance of pre-emption reduces in the village area as well. Besides, the scope of application of pre-emption in case of agricultural land is also limited by the substituted section 96 of the SAT Act. The new section incorporates rigid provisions; only a co-sharer tenant by inheritance can apply for pre-emption but a co-sharer tenant by purchase or adjoining land owner cannot pre-empt.

Another important thing is that people are not so interested to bring a suit for pre-emption under Muslim Law; it is filed as civil suit and ad valorem court fee is to be paid and the proof of formalities of pre-emption under Muslim law is very tough. It is mentionable that the provisions of statutory laws shall not take away the right of pre-emption conferred on any person by the Muslim Law.

\section{Findings and Recommendation}

Pre-emption is a right of co-sharer tenant of a holding. It was very familiar to the Indian sub-continent and later in Bangladesh but with the changes of time, the application of pre-emption is now very limited. In the present society, the significance of pre-emption has been reduced rapidly. Now the people are so much busy with their lives and their jobs; they have no enough time who come to the adjacent property. Some people still uses the opportunity of making an application for pre-emption, particular in agricultural land when necessity arises; they have to face some legal complexity and the party purchased the land and improved the land also. Under these circumstances, the following steps should be taken:

i. A seven days notice should be hanged over the land which will be proposed to sell.

ii. A notice should be served after registration by the registered office with cost of purchaser. By this he can avoid subsequent complexity and he can improve his purchased land smoothly.

iii. The maximum time limitation of application for pre-emption should be six months (present it three years).

iv. Under amended sec. 96, a co-sharer tenant of holding by inheritance can only apply but such provision creates discrimination to the co-sharer tenant of holding by purchase (the problem has been explained in the point no. 2.2.8. of this paper). Such bar should be removed.

v. ADR should be introduced as compulsory to pre-emption process i.e. in order to bring a suit or an application for pre-emption one should first face ADR and then, in case of failure, ordinary process can apply.

\section{Conclusions}

The right of pre-emption is not a right to repurchase, but it is a right of substitution, entitling the pre-emptor to stand in the shoes of the purchaser. In past, the application of Pre-emption was high in Bangladesh; still today it does not lose its importance wholly but after substitution of section 96 the number of applications for pre-emption is reduced comparatively. This section limits the scope of bringing an application for pre-emption. The present statutory laws discourage people to come before court for pre-emption. Now the time is changed; it's the time of globalization; so who comes near the land of another is not getting importance and this approach is reflected on pre-emption in Bangladesh presently.

\section{REFERENCES}

[1] Syed Lutfor Rahman, Pre-emption Laws in Bangladesh, 1st Edition, Ain-Grantha Prokashak, Dhaka, 1984

[2] Khalid Rashid, Muslim Law, 4th Edition, Eastern Book Company, Lucknow, 2004

[3] M. Hedyatullah and Arshad Hedayatullah (Ed), Mulla's Principles of Mahomedan Law, 19th Edition, Tripathi,

[4] ASAF A. A. Fyzee, Outlines of Muhammadan Law, 4th Edition, Oxford University Press, Delhi

[5] Justice Mohammad Hamidul Haque, Trial of Civil Suits and Criminal Cases, 2010, P. 166

[6] The State Acquisition and Tenancy (Amendment) Act, 2006, (Act No. XXXIV of 2006), http// www. Bdlaws.govtbd. com

[7] The Non-Agricultural Tenancy Act, 1949, http// www. Bdlaws.govtbd. com 